\title{
Role of $\mathbf{V} \gamma \mathbf{9} \mathbf{V} \delta \mathbf{2}+\gamma \delta \mathbf{T}$ cells in juvenile idiopathic arthritis M Gerstein*1, A Bendersky², S Padeh ${ }^{1}$, I Bank ${ }^{2}$ and Y Berkun ${ }^{1}$
}

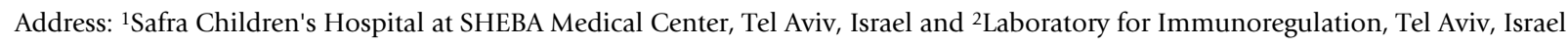

* Corresponding author

from 15th Paediatric Rheumatology European Society (PreS) Congress

London, UK. 14-17 September 2008

Published: 15 September 2008

Pediatric Rheumatology 2008, 6(Suppl I):P8 doi:10.1 186/1546-0096-6-SI-P8

This abstract is available from: http://www.ped-rheum.com/content/6/SI/P8

(c) 2008 Gerstein et al; licensee BioMed Central Ltd.

\section{Introduction}

$\mathrm{T}$ cells (TC) bearing $\mathrm{V} \gamma 9 \mathrm{~V} \delta 2+\gamma \delta \mathrm{TC}$ receptor (TCR), are a subset of innate CD4-CD8- TC pro-inflammatory and immunoregulatory TC recognizing non-peptidic phosphorylated mediator isopentenyl pyrophosphate (IPP) in the mevalonate pathway. The role $\mathrm{V} \gamma 9 \mathrm{~V} \delta 2+\mathrm{TC}$ has never been explored in JIA joints.

\section{Patients and methods}

Mononuclear cells (MC) isolated from synovial fluids (SF) of 47 patients with monoarticular $(\mathrm{M}, \mathrm{n}=11)$, pauciarticular $(\mathrm{P}, \mathrm{n}=19)$, extended $(\mathrm{E}, \mathrm{n}=5)$, polyarticular $($ Po, $\mathrm{n}=2)$, systemic $(\mathrm{S}, \mathrm{n}=4)$, psoriatic (Ps, $\mathrm{n}=4)$, enthesitis related $(S p, n=2)$ JIA were dually stained with monoclonal antibodies to $\mathrm{CD} 3$ and variable $(\mathrm{V})$ regions of the $\gamma \delta$ TCR. Flow cytometry of fresh SFMC and following in vitro 10 days stimulation with $0.5 \mathrm{mg} / \mathrm{ml}$ IPP plus $100 \mathrm{IU} / \mathrm{ml}$ interleukin-2 (IL-2) was performed.

\section{Results}

V $\gamma 9$ V $82+\mathrm{TC}$ constituted $6.8 \pm 1.3 \%, 6.4 \pm 0.9 \%, 4.6 \pm$ $1.0 \%, 3.8 \pm 3.6 \%, 5.6 \pm 1.6 \%, 6.1 \pm 0.1 \%$ and $1.3 \pm 0.8 \%$ of the SF CD3+cells in the M, P, E, Po, Ps, Sp and S JIA types respectively, and were significantly higher in ANA+ $(\mathrm{n}=19)$ than ANA- $(\mathrm{n}=22)$ patients $(7.8 \pm 0.9 \%$ vs $4.1 \pm$ $0.6 \% \mathrm{p}<0.004$, Student T test). IPP and IL-2 activated SFMC showed a greater expansion of $\mathrm{V} \gamma 9 \mathrm{~V} \delta 2+\mathrm{TC}$ of ANA $+(\mathrm{n}=12)$ than ANA- $(\mathrm{n}=18)$ patients $(61.2 \pm 17.1 \%$ vs $31.7 \pm 7.6 \%, \mathrm{p}<0.005)$ and of patients with $\mathrm{M}$ or $\mathrm{P}(\mathrm{n}$ $=11)$ relative to $S, E$ or Po $(n=6))$ JIA $(44.9 \pm 10.9$ vs 16.2 $\pm 10.5 \mathrm{p}<0.02)$.

\section{Conclusion}

$\mathrm{SF} V \gamma 9 \mathrm{~V} \delta 2+\mathrm{TC}$ responses are stronger in $\mathrm{M}$ and $\mathrm{P}$ than in $\mathrm{E}, \mathrm{Po}$, and S JIA and in ANA+ than - patients, suggesting that a potent $\mathrm{V} \gamma 9 \mathrm{~V} \delta 2+\mathrm{TC}$ response may augment acute inflammation while limiting progression to chronic and destructive arthritis. 